
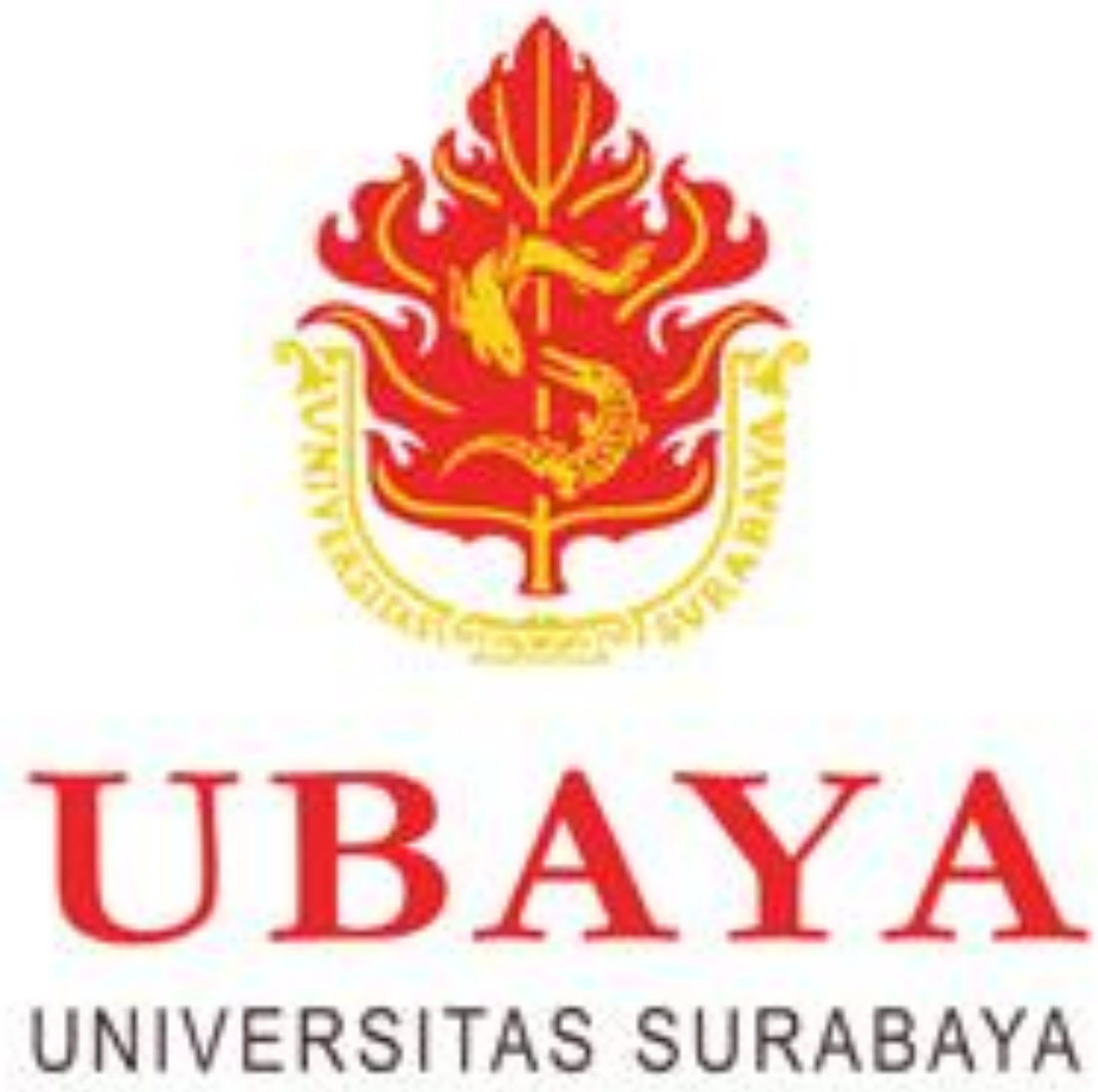

By :

Amelia

130518002 


\section{Strategies for Developing Mangrove Ecotourism in Riau Province Indonesia}

My team present the topic about "Tourism and Social Culture" and the care that was given is about Mengkapan Mangrove that is located in Riau Province. This article explain about the huge effect that tourism can make for the regional economy. Mengkapai Mangrove was open in 2016 and declared to be the leading ecotourism in Siak Regency and receive a special attention from the government. (Musadad \& Ibrahim, 2019).

The article was made to find the best strategy to develop the tourism sectors in the Mengkapai Mangrove Ecosystem. To find the answear the writters gather some information from the head of the destination, the head of non-profit organization, the head of local management, community leader, and some tourist. The writters ask them to filled some questionnaires that was devided into 4 segment, Streght, Weakness, Opportunities, and Thread. After they got the information, they will make scores from the responses that they got from the interview.

There are five key stakeholders in Mengapai Mangrove they are the Siak Tourism Office because they help the promotion for the Mengkapai Mangrove. The local tourism management because they help them to build the facilities for the tourism and managing tourist visits. The people of Mengkapai village, they provide some parking lot when there are many tourist visiting the mangrove. PT. Malcca Strait, because they donated some wood to build the bridges, they also organized several CSR progams to the Mengkapan Mangkapan Mangrove, such as planting mangrove seedlings and donnating some funds for the opperation expense for this mangrove. (Musadad \& Ibrahim, 2019)

From the SWOT Matrix that is shows in the picture that is attach on their article we can conclude that the Mengkpapai Mangrove already has a good acsess to the destination that will help visitors to find the place more easier. (Musadad \& Ibrahim, 2019)

Our team think that maybe the Mengkapai Mangrove need more promotion, the cheapest promotion can be done through social media, or maybe they need to make a travel packages that offer some fun activities rather than just visiting the mangrove, for example kayaking around the mangrove or seedling mangrove, or any other activities where visitors can also take part so it is not boring. 
Since the topic is about tourism and social culture, aside from this Mengkapai Mangrove I think that the conclusion in this article can be apply to most of the tourism destination in Indonesia that many people have not figure out yet. Indonesia has many exotic destinations, but not many people want to visit the place, because it is hidden and the acsess are limited. Not to mention about some local people there that want to get a profit by doing bad things, for example mark up the price for new visitors, asking to buy the ticket where clearly there is no ticket that need to be purchase. And many things that will harm us.

Also some of the tourist destination in Indonesia did not get enough spotlite that is needed to promote the destination, some of the destination usualy wait until there is people who wants to make a business opportunity there then help them to promote the destination.

So I think, it is time to fix the acsess to many of Indonesia's touristsm destination, because with many of good destination in Indonesia we can attract many more tourist to fix the economy sector for the local people that live surround the destinations. 


\section{References}

Musadad, \& Ibrahim, M. (2019). ECOTOURISM IN RIAU PROVINCE, INDONESIA . 86-94. 